\title{
Possibilities of using stability lobe diagram for stability prediction of high speed milling of thin- walled details
}

\author{
Yu. Vnukov ${ }^{1} \bullet$ A. Germashev ${ }^{1} \bullet$ V. $\operatorname{Logominov}^{1} \bullet$ V. $\operatorname{Kryshtal}^{2}$ \\ 1 - Zaporizhzhya National Technical University, Zaporizhzhya, Ukraine; \\ 2 - Ivchenko-Progress, Zaporizhzhya, Ukraine
}

Received: 20 March 2017 / Accepted: 05 April 2017

\begin{abstract}
High-speed milling is a cost and time effective process, which becomes more popular nowadays. It is especially available at milling of thin-walled structures of airfoil components. Manufacturer often faced with problem of producing thin-walled parts due to vibration and stability lobes theory in a lot of cases does not allow to avoid this problem by choosing the appropriate cutting conditions. In practice cutting condition for milling of thin walled detail is usually obtained by experimental way. In this paper authors present main differences of thin-walled end milling from classical end milling and show features of thin-walled end milling process and aspects, which effect on quality of surface finish. The aim of the paper is to validate that at high speed thin-walled end milling not only chatter is the reason of unstable cutting condition. Evaluation of stability, obtained by experimental tests, was compared with stability lobe diagram.
\end{abstract}

Keywords: Thin-walled detail; high-speed milling; chatter; stability; surface finish

\section{Introduction}

A collaborative motion of a cutting tool and a workpiece in cutting processes leads to self-excited vibrations, also called chatter. If a rigidity of one of system component is low or volume of removed material is too big, value of chatter increases, which cause to poor surface finish, manufacturing tool wear and other.

The basic principles of chatter theory have been developed by Tobias [1] and Tlusty [2], who studied the interaction of the dynamics of the machine tool structure with the dynamics of the cutting process. They defined the regeneration phenomenon and the mode coupling effect as the principle chatter mechanisms. Merritt [3] presented stability theory for orthogonal turning. His approaches were later adopted by many researchers [4, 5] and leaded to developing of fundamentals of chatter prediction by using the so called stability lobes diagrams. The most of approaches have been conducted on turning despite the fact chatter occurs in different metal cutting process. Tlusty [6] and Tlusty and Ismail [7] made a detailed analysis of milling stability, based on phenomenon of regenerative chatter. Further for stability prediction of milling to chatter was added intermittent nature of this process $[8,9,10,11,12,13]$.

After developing 5 axis milling machine with $\mathrm{CNC}$ became possible to produce thin-walled monolithic parts with complex shapes and configurations of surfaces. They have excellent strength to weight ratio and effectively use in aerospace and other industries. Also monolithic parts have better accuracy, balance and need less machining time for their producing than assembling elements. Examples of such thin walled details are blisks, impellers, blades of gas turbine engine. However, a major negative factor in their producing is appearance of vibrations associated with their thin-walled structure. Stability of the milling process for thin-walled components producing one of the most complex task nowadays in investigation of cutting metals. The authors [14] concluded that using stability lobe diagram is not accurate for the milling flexible workpiece.

In this paper the features of end milling of thin walled-details are analyzed. Next, the way of stability lobe diagram calculation, which include real number of the waves on cutting surface, is presented.

The primary objective of the paper is to validate that at high speed thin-walled end milling not only chatter is the reason of unstable cutting condition. At this process take place other regularities which determine stable as well as unstable cutting condition and these regularities based not on chatter theory.

Paper is organized as follows. In section 2 the main differences of thin-walled milling from classical end milling, which determine main aspects of processing stability is shown. Further in section 3 stability analyses for classical and for thin-walled end milling is proposed. Two spindle speed range, which determine features of processing and aspects

$\triangle$ Yu. Vnukov 
effected on quality of surface finish is described in section 4. The experimental methodology of stability determination for high-speed milling of thin-walled detail is also presented in this section. In section 5 experimental setup is presented. Experimental results and simulation is shown in section 6. Discussion and conclusion is presented in section 7 .

\section{Features of thin-walled end milling process}

Kinematics of the machine-tool movement during thin-walled elements processing is important to clearly understand features of the machining process. To make complex shape of the detail the axial depth of cut should be low. The radial depth of cut is also limited by thin walled structure of the detail, because big cutting forces causes to big deflection of the detail and bad dimensional accuracy. Low radial and axial immersion during milling process of thinwalled elements contributes to periodical loss of contact between mill and detail. It happens when tooth exit from the engagement with allowance after cutting process and next tooth hasn't enter to the allowance yet. The time between

\section{Classical end milling}

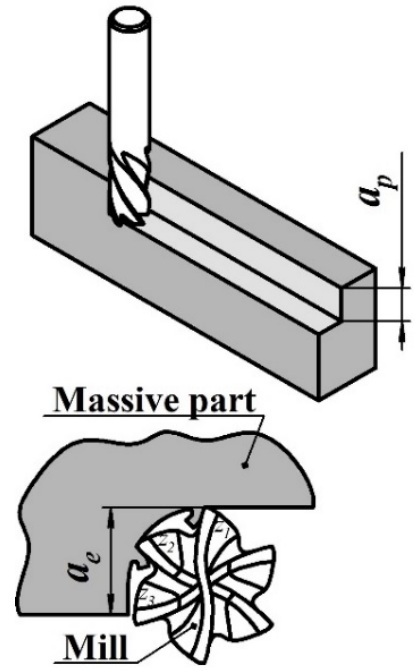

Milling of thin-walled parts

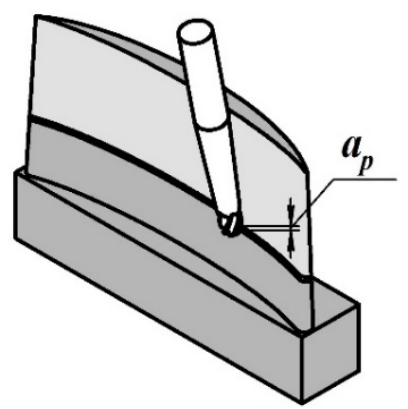

Thin-walled part

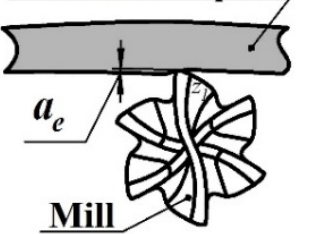

Fig. 1. Features of classical and thin-walled end milling cutting of two neighboring teeth is proposed to call idle running time. Finish milling of thin walled detail always occurs with idle running. So the main difference of thin-walled end milling from the classical end milling that this process is intermittent and we have deal with flexible detail so the tool is much more rigid than the workpiece.Due to intermittent character of thin-walled end milling process the cutting force exist periodically (Fig 2b) in comparison with classical end milling (Fig 2b). It varies with the angle of the cutting edge. By including the rotation of the spindle is able to observe that the cutting force varies in time and that the forces generated by the teeth are an external excitation that cause forced vibration. The frequency of this excitation depends from spindle speed and number of the teeth. During idle running cutting force doesn't exist and thin-walled detail makes free movement according to the law of free damped oscillation until the next tooth entrance to the allowance.
Classical end milling

$\mathrm{P}$

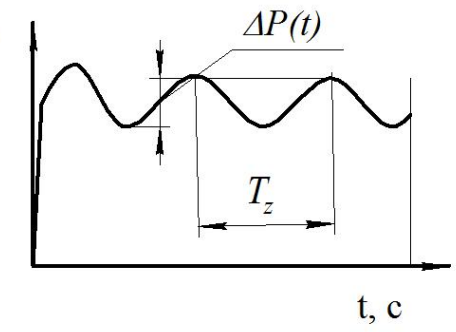

a

Milling of thin-walled parts

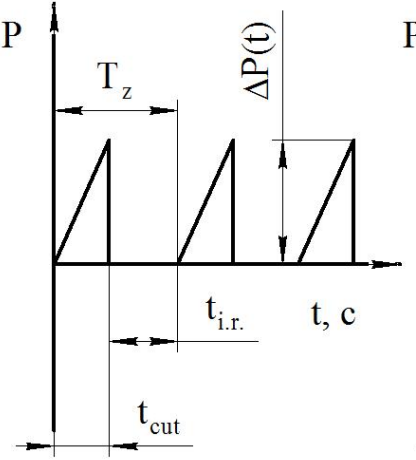

Up milling

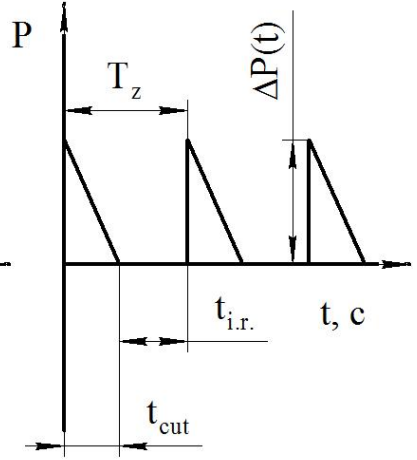

Down milling

$\mathrm{b}$

Fig. 2. Fluctuation of cutting forces during classical and thin-walled end milling

By taking into account cylindrical end milling condition time of cutting defined by [15]

$$
t_{\text {cut }}=\frac{60}{\pi \cdot D_{\text {mill }} \cdot \Omega} \cdot\left[\frac{D_{\text {mill }}}{2} \cdot\left(\frac{\pi}{2}-\arccos \left(1-\frac{2 \cdot a_{e}}{D_{\text {mill }}}\right)\right)+\frac{1}{2} F_{z}+\operatorname{tg} \omega \cdot a_{p}\right]
$$

where $D_{\text {mill }}$ : diameter of the mill,

$\Omega$ : spindle speed 
$F_{z}:$ feed per tooth

$\omega$ : helix angel of the mill

$a_{p}:$ axial depth of cut

$a_{e}$ : radial depth of cut

The passage time of two teeth is given by

$$
T_{z}=\frac{60}{N_{t} \cdot \Omega}
$$

$N_{t}:$ number of the teeth

In case of thin-walled end milling $t_{c u t}<T_{z}$

\section{Stability analyses for classical and for thin-walled end milling}

Nowadays to determine stability of metal cutting operations are widely used stability lobe diagrams, which allow to calculate the critical depth of cut at the highest available spindle speed. They are based on regenerative chatter theory. Depending on the spindle speed, the critical depth of cut can be calculated with the help of the following formulas:

$$
a_{p \lim }=-\frac{1}{\left(\frac{N_{t}}{2 \pi}\right) a_{y y} K_{t} 2 \operatorname{Re}(\mathrm{FRF})}
$$

where $N_{t}$ is the number of the teeth on the mill,

$K_{t}$ is tangential cutting force,

$\operatorname{Re}(\mathrm{FRF})$ is a real part of the structural transfer function of a system with single degree of freedom.

$a_{y y}$ is the directional dynamic milling coefficient in y direction.

$$
a_{y y}=\frac{1}{2}\left[-\cos \left(2 \varphi_{c}\right)-2 K_{r} \varphi_{c}-K_{r} \sin \left(2 \varphi_{c}\right)\right]_{\varphi_{s t}}^{\varphi_{e x}}
$$

For down milling it is usually assumed that tool exit from the allowance at $\varphi_{e}=180^{\circ}=\pi$, while the start angle, $\varphi_{s}$, by taking into account cylindrical end milling condition defined by [15]:

$$
\varphi_{s}=\frac{\pi}{2}+\arccos \left(1-\frac{2 a_{e}}{D_{\text {mill }}}\right)-\frac{f_{t}}{D_{\text {mill }}}-\frac{2 \operatorname{tg}(\omega) a_{p}}{D_{\text {mill }}}
$$

where $\varphi_{c}$ is the angle of contact of the tool and workpiece when cutting edge in the immersion zone.

Finally, to obtain corresponding spindle speed for chatter frequency $-f_{c}$ following expression is used:

$$
\Omega=\frac{60 f_{c}}{N_{t}\left(N+1-\frac{1}{\pi} \arctan \left(\frac{\mathrm{Re}\left[\mathrm{FRF}_{\text {orient }}\right]}{\operatorname{Im}\left[\mathrm{FRF}_{\text {orient }}\right]}\right)\right.}
$$

where $N$ is the whole number of full vibration cycles between passages of two teeth

Above formulas allow to predict a set of spindle speeds with locally optimum stability at integer fractions of the natural frequency of the most flexible mode of the system. However, assumptions of traditional regenerative stability theory become invalid for highly interrupted machining, where the ratio of time spent cutting to not is small [16]. Davies et. al. propose a new stability theory for interrupted machining that predicts a doubling in the number of optimally stable speeds.

Unlike turning operations, which are characterized by a well-defined single chatter frequency according to the Hopf bifurcation of autonomous systems, milling operations, being parametrically excited systems, present multiple vibration frequencies [17]. A new series of extra stability lobes arise in addition to the Hopf lobes of turning. The numerical calculation of the relevant characteristic multipliers shows a new kind of bifurcation phenomenon: these extra lobes are related to period two or flip bifurcation [18]. Along the flip lobes, the basic frequency of the vibrations is equal to half of tooth passing frequency. Along the Hopf lobes, quasiperiodic vibrations arise. It should be mentioned that flip instability is directly related to the time-periodic nature of the milling process. It occurs mostly for operations with small radial immersion [17].

Thus, for milling operation of thin-walled details which are processed with low immersion, stability lobes have additional peaks related with period doubling and hence extra stable regions in comparison with classical theory. However, the authors noticed another principle difference thin-walled end milling from classical milling related with the relatively short length of cutting surface. Taking into account intermittency of milling process there is not possible 
to achieve cutting condition which allows to workpiece makes full vibration cycle between passage of two neighboring teeth. It means that number of the waves on cutting surface is less than included into calculation of classical stability lobe diagram. For evaluation of this phenomenon should be defined the ration of cutting time and tooth passage period.

$$
K_{i . c .}=\frac{t_{c u t}}{T_{z}}
$$

$K_{\text {i.c. }}$ : cutting intermittency coefficient

In case of thin-walled end milling $K_{i . c .}<1$

In order to obtain real number of the waves on cutting surface in stability lobe diagram calculation this coefficient should be included in equation (6). Such action changes location of lobes series, but do not influence on their magnitude and number.

$$
\Omega^{\prime}=\frac{60 f_{c} K_{i, c .}}{N_{t}\left(N+1-\frac{1}{\pi} \arctan \left(\frac{\operatorname{Re}\left[\mathrm{FRF}_{\text {orient }}\right]}{\operatorname{Im}\left[\mathrm{FRF}_{\text {orient }}\right]}\right)\right)}
$$

The authors agreed that periodical loss of contact between mill and detail leads to non-linearity of the system and taking into account just the real number of the waves on cutting surface is not exact solution of stability for this process, but it is a good way to show that the main reason of vibration at high speed milling is not self-exited oscillation.

\section{Speed zones, which determine parameters effected on quality of processing and experimental methodology of their evaluation}

In case of milling of thin walled-detail with complex shape cutting edge in the immersion zone usually less than $50 \%$ from period of tooth passing. Therefore, the lobes should be in lower spindle speed range in comparing with classical approach, because tooth pass through the less number of the waves due to shorter cutting length. Taking this fact into account, the most of the thin walled detail should have stability at high-speed milling. However, they do not and behaviour of the detail totally changes with changing of spindle speed. The main reason of instability is intermittent nature of machining process. In this condition exist two mechanism of vibration appearance. The first one is related with self-exited vibration. It takes place when we are able to observe waves on cutting surface. In this case quality of surface finish depends on value of chatter, which is characterized by parameter $P_{\text {chatter }}$ (fig. 3). With increasing spindle speed the cutting time is reduced. At some moment it become so little that system is not able to make even one selfexited oscillation during cutting process. It guaranties smooth cutting surface without waves. However, in this condition is also possible appearance of vibration and their value might be much more bigger than due to self-exited oscillation. In this case quality of surface finish depends from the position of the detail when tooth starts to cut. Thus, to determine whether cutting is stable or not we should analyze oscillation of the detail during idle running. The parameter, which characterized cutting condition at thin-walled high-speed end milling is peak-to-peak value of detail deflection when

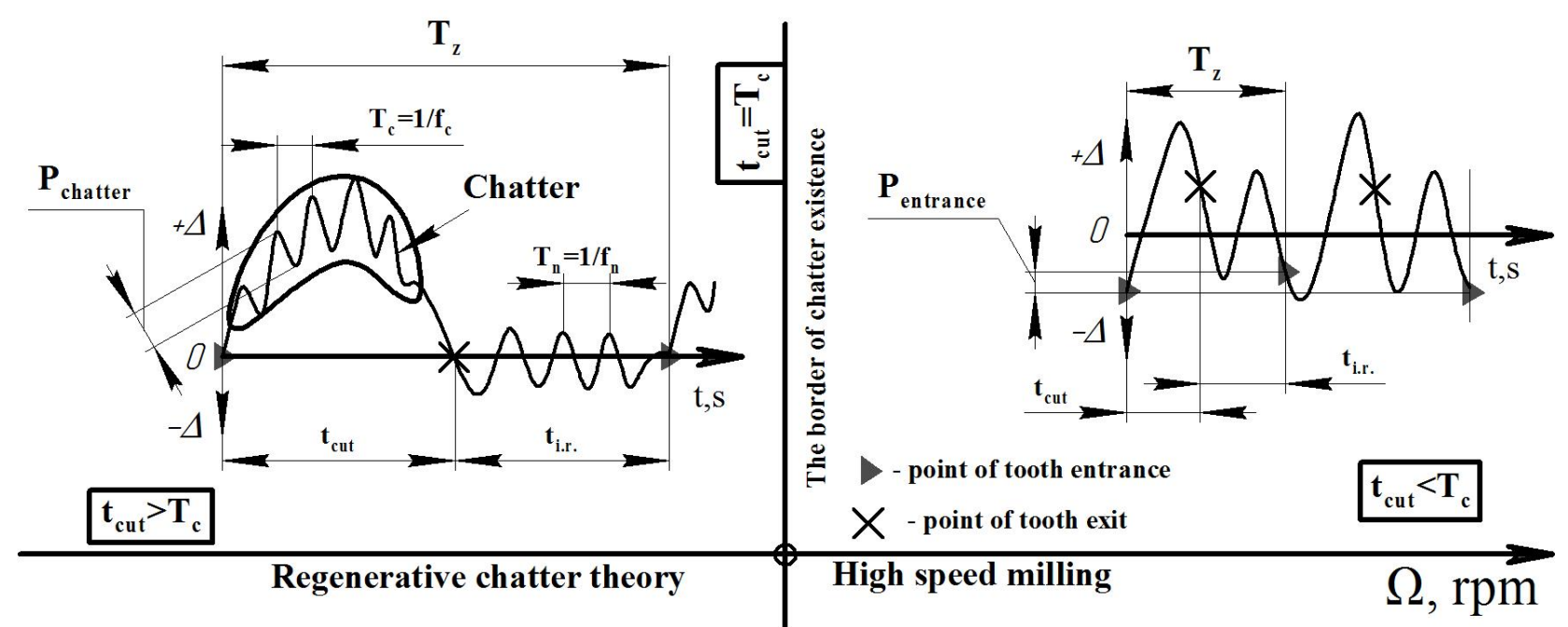

Fig. 3. Two spindle speed ranges, which determine features of thin-walled end milling

tooth starts to cut $\left(P_{\text {entrance }}\right)$. This parameter analyse difference between maximum and minimum deflection of the detail from equilibrium position at point of tooth entrance. To obtain information about machining process should be analysed all data during processing.

The border of chatter existence is determined by 


$$
\Omega_{c . b .}=\frac{60 f_{c}}{\pi \cdot D_{\text {mill }}} \cdot\left[\frac{D_{\text {mill }}}{2} \cdot\left(\frac{\pi}{2}-\arccos \left(1-\frac{2 \cdot a_{e}}{D_{\text {mill }}}\right)\right)+\frac{1}{2} F_{z}+\operatorname{tg} \omega \cdot a_{p}\right]
$$

Experimental setup

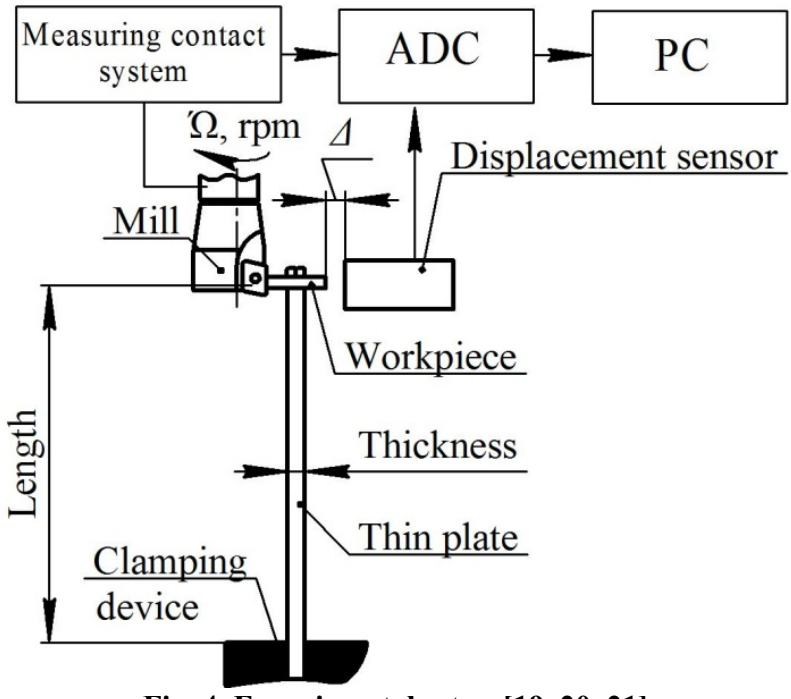

This value divides whole spindle speed range of machine-tool on two zones. If spindle speed $\Omega$ lower than $\Omega_{c . b .}$ milling process occurs at chatter existence domain and quality of machined surface is determined by parameters of self-exited vibration (chatter). Otherwise, when $\Omega$ bigger than $\Omega_{c . b \text {. }}$ quality of surface finish is determined by parameters of detail oscillation during idle running time.

A set of milling experiments was conducted on a CNC machine. The workpiece is a $6 \mathrm{~mm}$ steel plate. It was cantilevered by clamping one end in special device $[19,20$, 21] a clamped length of $80 \mathrm{~mm}$ and a width of $60 \mathrm{~mm}$. On the free-end was clamped steel workpiece (S235), which was down-milled using a high-speed-steel, helical, fourflute tool with a diameter of $19 \mathrm{~mm}$. Workpiece vibrations were measured by using displacement sensor. Contact condition between mill and workpiece were measured by developed system [22]. Properties of the thin plate with workpieces is shown in table 1 .

Table 1

Modal properties of the thin plate with workpieces

\begin{tabular}{ccccc}
\hline natural frequency $f_{n}(\mathrm{~Hz})$ & damping ratio $\xi$ & stiffness $k(\mathrm{~N} / \mathrm{m})$ & $K_{t}, \mathrm{~N} / \mathrm{mm}^{2}$ & $K_{r}$ \\
\hline 560 & 0,01 & $992 \times 10^{3}$ & 2400 & 0.9 \\
\hline
\end{tabular}

In all of the experimental tests, the axial depth of cut was fixed at $2 \mathrm{~mm}$ and the feed per tooth was fixed at $0.05 \mathrm{~mm}$ and the radial depth of cut was fixed at $0.5 \mathrm{~mm}$. No coolant was used during cutting.

One set of experiments was conducted. During experiments the dynamics were measured at every $100 \mathrm{rpm}$ between 500rpm and $10000 \mathrm{rpm}$. At the milling tests was evaluated parameter $P_{\text {entrance }}$ (Fig. 3).

\section{Results}

In fig 3, stability lobe diagram obtained by taking into account classical theory is shown. This diagram is not accurate for thin-walled end milling because it does not consider intermittent nature of this process. Therefore, the stability lobe diagram which include in calculation real number of the waves on cutting surface (eq. 6) is represented in fig 4. Such approach moves lobes to lower spindle speed range in comparing with classical theory. Prediction guaranty stable cutting condition with axial depth of cut $a_{e}=0,5 \mathrm{~mm}$ at every spindle speed after 5000rpm. It is also possible to increase parameter $a_{e}$, but as was noted it does not require for thin walled details with complex shape.

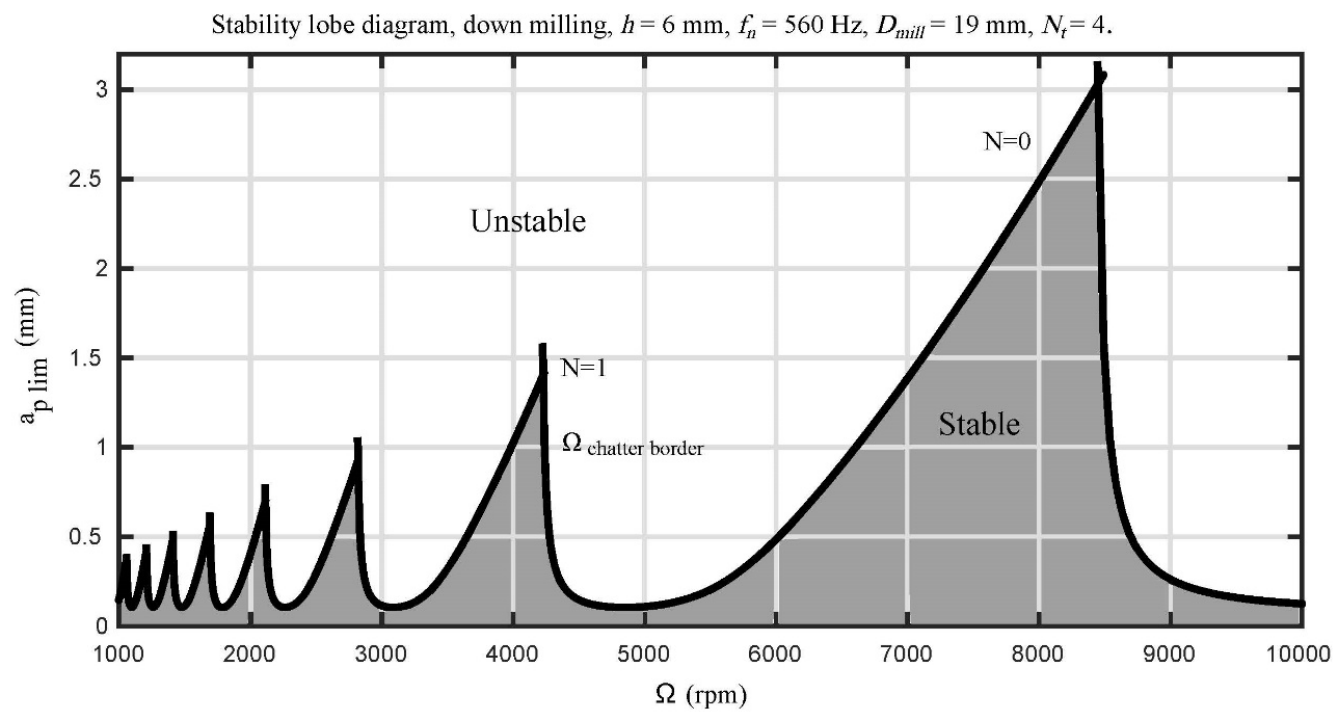

Fig. 5. Classical stability lobe diagram 


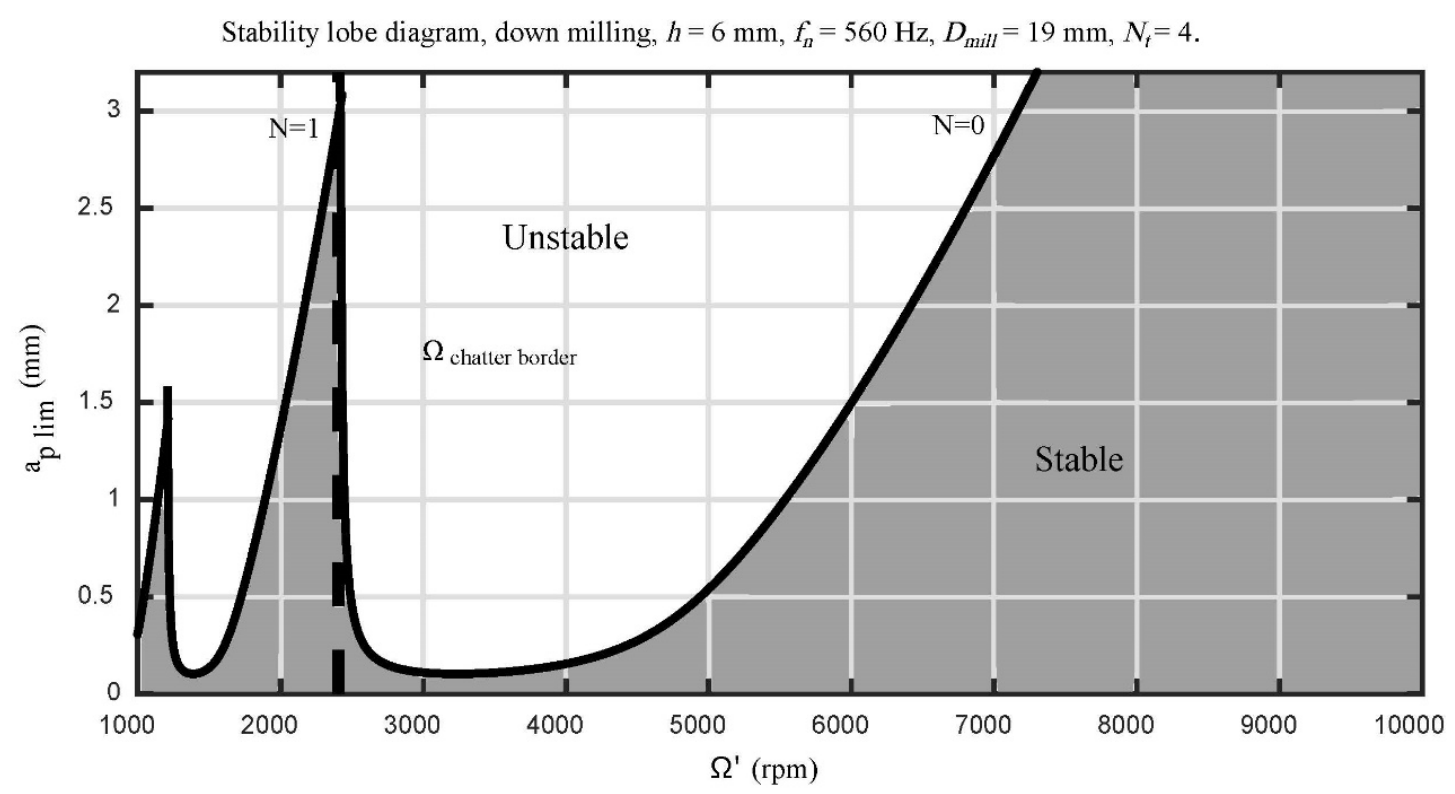

Fig. 6. Stability lobe diagram, which takes into account real number of the waves on cutting surface

Experimental determination of peak-to-peak value of workpiece deflection from the equilibrium position when tooth starts to cut is shown on fig 5. Unlike stability lobe diagram the minimum values of the curve show maximum stability of the cutting process and guaranty the best quality of surface finish. Respectively maximum values of parameter $P_{\text {entrance }}$ show the most unstable milling process, which cause to poor surface finish. Thus, this chart allows to define stable spindle speed and also evaluate quality of the machined surface if spindle speed is bigger than $\Omega_{c . b .}$. In case of spindle speed lower then $\Omega_{c . b \text {. }}$ should be evaluated parameter $P_{\text {chatter, }}$, which characterized value of self-exited oscillation.

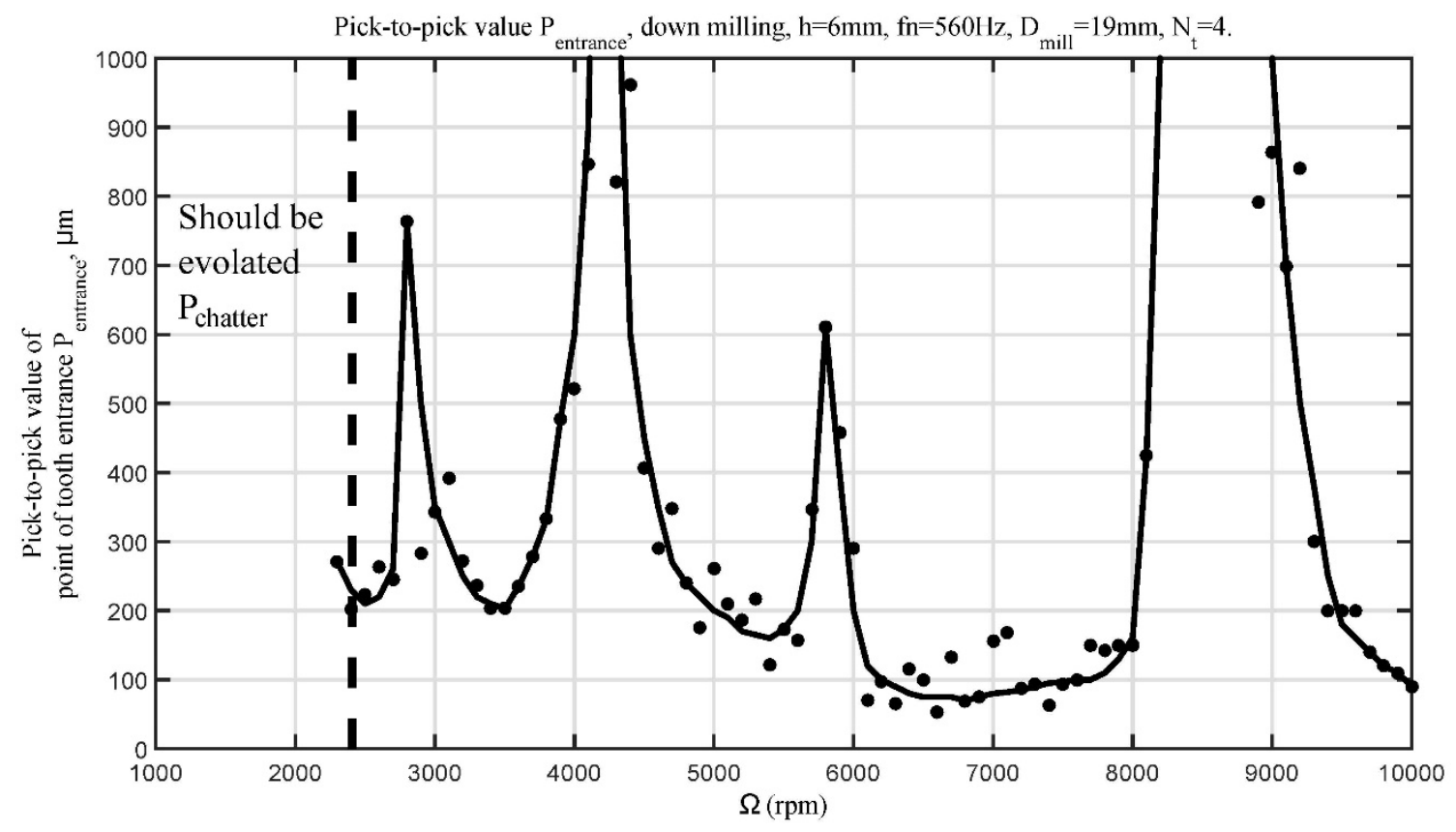

Fig. 7 Peak-to-peak value of detail deflection when tooth starts to cut vs spindle speed chart

\section{Discussion and conclusion}

Comparison of experimental tests (fig. 5) and stability lobe diagrams obtained by taking into account real number of the waves on cutting surface (fig. 4) shows disagreements between experimental results and stability calculation. Disagreements from spindle speed $2400 \mathrm{rpm}$ to $6500 \mathrm{rpm}$, where we observe lobe N=0 on stability lobe diagram, related to the complexity of accurate calculation of the phase shift at thin-walled end milling due to high intermittency of this process. Connection between two cutting is interrupted by free movement of the detail. This 
phenomenon needs special research and discussion. Thus, in this spindle range we deals with four regions of stable cutting and three of unstable one (2800-3200 rpm, 3600-4800 rpm and 5600-6100) in spite of the fact stability lobe diagram show unstable cutting in whole this range. After $6500 \mathrm{rpm}$ the simulation shows stable cutting, but at experimental tests was obtained region with big vibrations (8000-9700 rpm).

Thus, the milling tests show that if we do not have full number of the waves on cutting surface, and part of the wave, which is lived from the previous cutting is insignificant (very small) according to the chatter theory and stability lobe diagram guaranty stable cutting we able to have a stable as well as unstable cutting process. It means that for thinwalled end milling not only chatter is the reason of unstable cutting condition. In this case the other regularities which effect on stability of the system take place. Such situation is a pretty common for thin walled end milling due to high intermittency of this process. These regularities relate with complex interaction between parameters of milling process and characteristics of thin-walled detail and their investigation needs special consideration.

Summing up, the next conclusions can be drawn:

The main difference of thin-walled end milling from the classical end milling that this process is intermittent and connection between two cutting is interrupted by free movement of the detail.

It is not possible to use the whole sense of stability lobe diagram for milling of thin-walled details due to increasing of axial depth of cut is limited by the shape of the detail.

The number of the waves on cutting surface during thin walled end milling is less than included into calculation of classical stability lobe diagram

Although part of the wave, which is left on cutting surface after previous cutting, do not produce unstable cutting processing according to the chatter theory and stability lobe diagram guarantees stable cutting we able to have a stable as well as unstable cutting process.

For high speed thin-walled end milling not only chatter is the reason of unstable cutting condition

Regularities which effect on stability of thin walled end milling relate with complex interaction between parameters of milling process and characteristics of thin-walled detail and their investigation needs special consideration.

\title{
Можливість використання пелюсткових діаграм для прогнозування вібросталості високошвидкісного фрезерування тонкостінних деталей
}

\author{
Ю.М. Внуков, А.І. Гермашев, В.О. Логомінов, В.О. Кришталь \\ Анотація. Високошвидкісне фрезерування - продуктивний і ефективний процес, який стає все більш популярним в наш час. \\ Особливо при фрезеруванні тонкостінних елементів деталей з аеродинамічними поверхнями. На виробництві часто \\ стикаються з проблемою отримання тонкостінних деталей пов'язаною з виникненням вібраиій і теорія побудови діаграм \\ вібросталості в більшості випадків не дозволяє уникнути иієї проблеми иляхом вибору відповідних умов різання. На \\ практиці режсими обробки з мінімальними вібрачіями для фрезерування тонкостінних деталей визначаються, як правило, \\ експериментальним шляхом. В даній роботі автори представляють основні відмінності кінцевого фрезерування \\ тонкостінних деталей від класичного кінцевого фрезерування, показують особливості процесу фрезерування тонкостінних \\ деталей і аспекти, які впливають на якість обробленої поверхні. Метою даної роботи є підтвердження, щзо при високій \\ швидкості кінщевого фрезерування тонкостінних деталей причиною несталості процесу різання є не тільки виникнення \\ регенеративних коливань. Проведена порівняльна оцінка вібросталості, отриманої за допомогою розрахункового методу \\ та побудованою за експериментальними даними.
}

Ключові слова: Тонкостінні деталі, високошвидкісний фрезерної, балаканина, стабільність, поверхнева обробка

\section{Возможность использования лепестковых диаграмм для прогнозирования вибросталости высокоскоростного фрезерования тонкостенных деталей}

Ю.М. Внуков, А.И. Гермашев, В.О. Логоминов, В.О. Кришталь

\footnotetext{
Аннотация. Высокоскоростное фрезерование - производительный и эффективный проиесс, который становится все более популярным в наме время. Особенно при фрезеровании тонкостенных элементов деталей с аэродинамическими поверхностями. На производстве часто сталкиваются с проблемой получения тонкостенных деталей связанной $c$ возникновением вибраций. Теория построения диаграмм виброустойчивости в большинстве случаев не позволяет устранить эту проблему путем выбора соответствующих условий резания. На практике режимы обработки с минимальными вибрациями для фрезерования тонкостенных деталей определяются, как правило, экспериментальным путем. В данной работе авторы представляют основные отличия концевого фррезерования тонкостенных деталей от классического конщевого фрезерования, показывают особенности прочесса фрезерования тонкостенных деталей $u$ аспекты, которые влияют на качество обработанной поверхности. Целью данной работы является подтверждение
} 
гипотезы, что при высокоскоростном конщевом фрезеровании тонкостенных деталей причиной неустойчивости процесса резания является не только возникновение регенеративных колебаний. Проведена сравнительная оценка виброустойчивости, полученная с помощью расчетного метода и построенной по экспериментальным данным.

Ключевые слова: Тонкостенные детали, высокоскоростное фрезерование, вибрация, устойчивость, чистота поверхности

\section{References}

1. Tobias, S. A. (1965), Machine Tool Vibration, Wiley, N.Y.

2. Koenigsberger, I., Tlusty, J. (1971), Structures of Machine Tools, Pergamon Press.

3. Merritt, H. E. (1965), Theory of Self-Excited Machine Tool Chatter, ASME Journal of Engineering for Industry, Vol. 87, pp. 447-454.

4. Week, M. (1985), Handbook of Machine Tools, Vol. 4, Wiley, N. Y.

5. Minis, I., Magrab, E., and Pandelidis, I. (1990), Improved Methods for the Prediction of Chatter in Turning. Part III: A Generalized Linear Theory, ASME Journal of Engineering for Industry, Vol. 112, pp. 28-35.

6. Tlusty, J. (1986), 'Dynamics of high-speed milling', Journal of Engineering for Industry 108, 59-67.

7. Tlusty, J., Ismail, F. (1983), 'Special aspects of chatter in milling', Journal of Vibration, Acoustics, Stress, and Reliability in Design 105, P. pp. 24-32.

8. Shridar, R., Hohn, R. E., Long, G. W. (1968) A general formulation of the milling process equation, Journal of Engineering for Industry 90, pp. 317-324.

9. Shridar, R., Hohn, R. E., Long, G. W. (1968), A stability algorithm for the general milling process, Journal of Engineering for Industry 90, pp. 330-334 .

10. Shridar, R., Hohn, R. E., Long, G. W. (1968), A stability algorithm for a special case of the milling process, Journal of Engineering for Industry 90, pp. 325-329.

11. Minis, I. and Yanushevsky, R. (1993), A new theoretical approach for prediction of chatter in milling, Journal of Engineering for Industry 115, pp. 1-8.

12. Altintas, Y. and Lee, P. (1996), A general mechanics and dynamics model for helical end mills, Annals of the CIRP 45(1), pp. 59-64.

13. Smith, S. and Tlusty, J. (1991), An overview of modelling and simulation of the milling process, ASME Journal of Engineering for Industry 113, pp. 169-175.

14. Rusinek, R. and Zaleski, K. (2016), 'Dynamics of thin-walled element milling expressed by recurrence analysis', Meccanica. An International Journal of Theoretical and Applied Mechanics, Vol. 51, Issue 6, pp. 1275-1286.

15. Vnukov Y.N., Djadja S.I., Kozlova E.B., Chernovol N.N. (2014), Analyses of contact features of cutting tool and detail in cylindrical end milling, Journal of Engineering Science, Vol 4. - pp. 1-7.

16. Davies, M. A., Pratt, J. R., Dutterer, B., and Burns, T. J. (2000), The stability of low radial immersion milling, CIRP AnnalsManufacturing Technology 49 (1), pp. 37-40.

17. Insperger, T. and Stépán, G. (2011), Semi-discretization for time-delay systems: stability and engineering applications (Vol. 178). Springer Science \& Business Media, 174 p.

18. Insperger, T., and Stépán, G. (2004), Vibration Frequencies in High-Speed Milling Processes or a Positive Answer to Davies, Pratt, Dutterer and Burns T. Insperger, J. Manuf. Sci. Eng 126 (3), pp. 481-487.

19. Logominov, V., Germashev, A., Diadia, S., and Kozlova, O. (2014) Testbench for study of oscillations at final milling of part cylindrical thin-walled elements, $12 \mathrm{p}$.

20. Vnukov, Y., Hermashev, A., Kuchuhurov, M., Diadia, S., Kozlova, O. (2015), Stand for investigation of workpiece oscillating process under cylindrical cutting, $11 \mathrm{p}$.

21. Vnukov, Y., Lovominov, V., and Kamorkin, P. (2014), Stand for research mechanical oscillations in end milling of flexible workpieces by end mill, Cutting and tool in technological system: International ScientificTechnical Collection, 80, pp. 32-37.

22. Vnukov Y.N., Germashev A.I., Djadja S.I., Kozlova E.B. (2015), Methodology of contact condition determination of the tool and thin-walled detail during end milling, Cutting \& tool in technological system: International ScientificTechnical Collection, NTU "KhPI", Edition 85, pp. 48-55. 